\title{
本邦產リョクエン鉱一ミメット鉱系 鉱物について（第二報）
}

On the Pyromorphite-Mimetite Series Found in Japan (Rept. 2)

$$
\text { 牟田 邦 彥* (Kunihiko Muta) }
$$

\section{1. 前求}

第 1 報】では主として産状，形態及びその化学組成につんて述べた。今 回は主としてリョクェン鉱系鉱物** の微量成分と，i）形態及び色との関 係, ii) 初生鉱床の成因との関係, iii) 初生鉱物 (とくにホウェン鉱) 中の微 量成分との比較, 等につんて考察する。

\section{2. 分 光 分 析}

（1）試 料 第1因註に分光分析を行つた試料の産地を鉱床別に列郘 した。

（2）分光分析 双眼顕微鏡にて充分選別したものを，さらに鉣物顕微鏡 下で不純物を取除き，分光分析の試料とした。分光分析の際の諸条件は次の とおりでする。

分光器：島津製 $\mathrm{QM} 60$ 型石英分光写真器, 補助電極：炭素棒, 露出時 間： 30 秒及び 1 分, 乾板：富士プロセス, 電流： $4.5 \mathrm{~A}$, 電压： $100 \mathrm{~V}$, 連続弧光法による***。

（3）分光分析の結果 分光分析によつて，リョクエン鉱系鉱物より検出 した成分は, $\mathrm{Ag}, \mathrm{As}, \mathrm{Al}, \mathrm{Ba}, \mathrm{Bi}, \mathrm{Cd}, \mathrm{Ca}, \mathrm{Cu}, \mathrm{Fe}, \mathrm{Ti}, \mathrm{Tl}, \mathrm{Mg}, \mathrm{Mn}, \mathrm{P}$, $\mathrm{Pb}, \mathrm{Sb}, \mathrm{Si}, \mathrm{Sn}, \mathrm{Sr}, \mathrm{V}$ 及び $\mathrm{Zn} の 21$ 元素である。これらのちち $\mathrm{Si}, \mathrm{Al}$ 及び $\mathrm{Mg}$ を除いた 15 元素につんては, 酸化鉛, 酸化亞鉛及び食塩中に混 じて作製した既知濃度標準試料と比較するてとによつて， $\mathrm{Ag}, \mathrm{Bi}, \mathrm{Sn} の$ 定 量及びその他の元素の半定量をていろみた（第 1 困）。

* 九州大学工学部採鉣学教室。

** リョクエン 鉱系鉱物と記載した場合にはリョクエン鉱一ミメット鉱禾鉱物のすべ てを意味する。しかしリョクエシ鉱と記載した場合にはリョクエン鉱のみを示し， ミメット鉱，含ヒ素リョクエン鉱を含まない。

***これらの細かいデータは近く発表の予定である。 


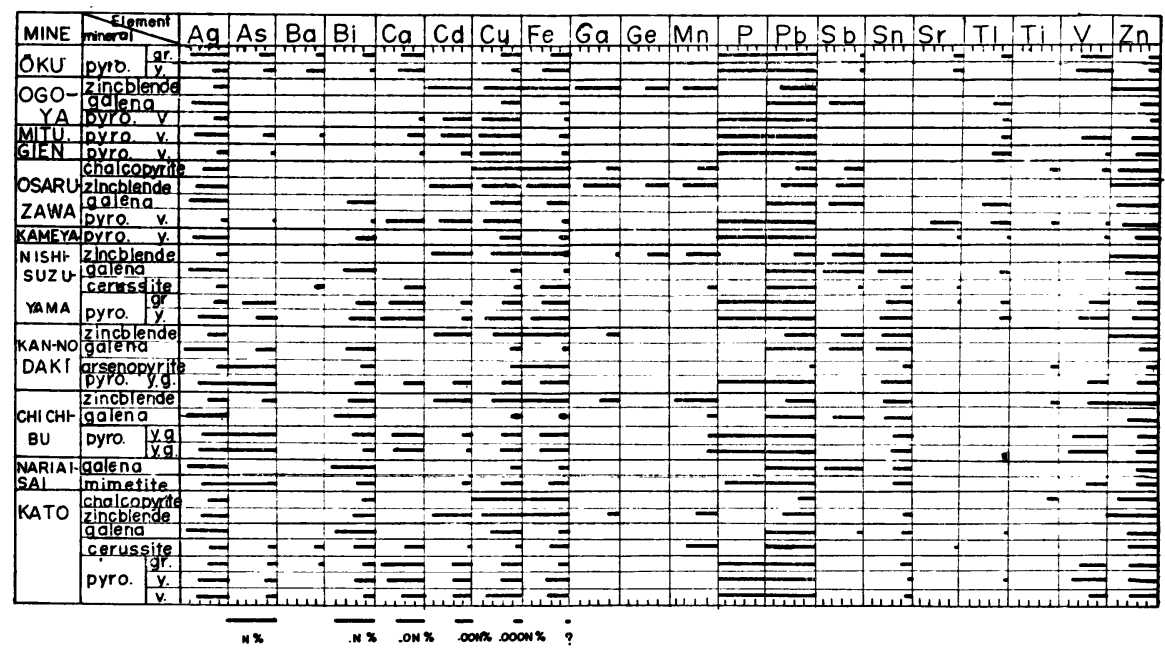

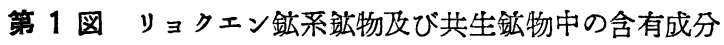

〔註〕

産地

釷床の型

北海道大㺵鉱山 石川県 尾小屋鉱山 静阙県三倉鉣山 宫城県地円鉣山 秋田紧 尾去沢鉱山

" 亀山盛鉱山 鹿児島県 西錫山鉱山 大分 県 観音滰旧坑 長崎 県 成相啋旧坑 埼玉県秩父鉣山 福岡紧河東銗山白要紀カコウ岩類に伴了中温熱水鉱床

第三紀末の火山岩類に伴 5

浅熱水鉱床

第三紀カコウ岩類に伴 5 中温〜高温熱水鉱床

pyro ‥ョョクンン鉱

y. …黄色種，gr. 緑色種， v. ·褐 赤色種

\section{3. 微量成分と色及び形態との関係}

(1) リョクエン鉱系鉱物の晶癖と色との関係本邦産リョクエン鉱系鉱 物の色には2', (i) 緑, (ii) 黄 (黄, オレンヂ黄, ワックス黄等), (iii) 赤 褐〜紫褐等の 3 種がある。乙れらの色の変化と, その晶譬との間には, 第 


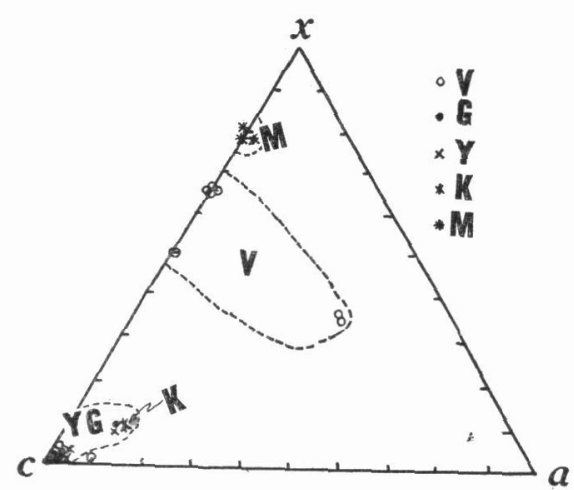

第 2 図リヨクエン鈗系鈗物の色

と晶癖との関係

（ $x, c$ 及び $a$ 面を頂点とした場合

の 3 面の現出度)

[誈]算出方法は例えば $x, c$ を主面とす る ( $m$ は一応考慮に入れず)場合, そ れぞれを 5 とし $a=0$ として上図に 記大した。たがし分析を行つた手持 のサンプルでは実際にその值を多数 の試料について検討したが，その他は 文献によつた。

$$
\begin{aligned}
& \text { G…緑 色 種 } \\
& \mathrm{Y} \text { ‥王色種 リョクエン鈗 } \\
& \mathrm{V} \cdots \text { 褐, 赤, 紫種 } \\
& \mathrm{K} \text { …含七素リョクエン鈗 } \\
& \text { M ‥ミメット鈗 }
\end{aligned}
$$

2 図及び第1表のような関係があ る。すを少ち（i）赤～紫褐色種 の大部分がつね齐 $x$ 面の発達顕 著で, かつ $m$ 面の発達も良好存長 杜状を示すものが多い(第 3 図)。 (ii) 黄〜緑色種注 $c$ 及び $m$ 面 よりをる短杜もしくは長㤬状の多 のに多く， $x$ 面泫小さんか, まを はとれ礼在く。(iii)しかしミッッ ト鉱では多く黄色で, かつ $x$ 面の 発達は良好でする。

以上のととから， $x$ 面の発達之 赤〜紫褐色汇着色する現象との間 には、をんらかの密接存結びつき がある5西われる。

（2）リョクエン鉱系鉱物の産状 と色之の関係第1表のように 赤褐～紫褐色種のもの梳，以和 銅鉣休より, 黄〜緑色種法鉛・ 亞鉛及びヒ素鉱を多産する鉱床よ り得られる。

黄及び緑色種は，しばしば単一 結晶内（また症結晶集合塊）でも

互いに漸移し，疗とんぼつね共生して産する。をとえば河東，大玫，西錫 山及び秩父等では，いホれも両者活密に共生し，(i) 緑色種注黄色種よりる 概して結晶が大をく，(ii）多産する。（iii）緑色種は黄色種よりも多少遅く 晶出したものが多い。（iv）一般にリョクエン鉱の晶出最も盛な時期には緑 色種を多く生するる等の傾向が西る。ととろが赤〜紫褐色種泣前二者と共生す る例少く，例えば河東鉣山では紫褐色種のみ単独産する。てのととはその 生成条件，とくに着色の原因が，前二者とか子存りの違いるととを示すもの 之思加礼名。

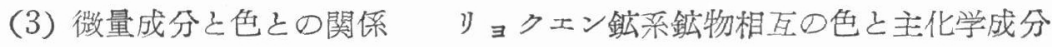




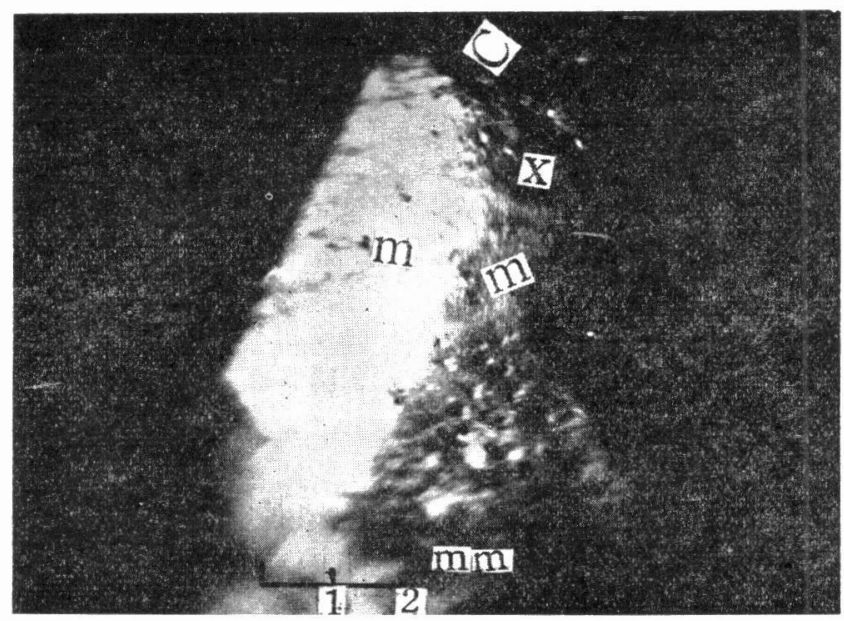

第 3 図 $x$ 面の発澾をみる紫褐色りョクエン鉣（三倉鉱山座）

第 1 表晶癖と色の関係

\begin{tabular}{|c|c|c|c|}
\hline \multicolumn{2}{|c|}{ 紫〜赤褐色種 } & \multicolumn{2}{|c|}{ 黄及び緑色種 } \\
\hline 地 & 癖 & 地 & 癖 \\
\hline \multirow[t]{2}{*}{ 秋田県大幕鉱山 } & \multirow{2}{*}{$\begin{array}{l}m, c, x \text { よりなる長柱 } \\
\text { 状, } x \text { の大なるもの } \\
\text { のり }\end{array}$} & 北海道大㺵 鉱山 & $m, c$. 小さく $a, x$. \\
\hline & & 秋田県急山盛鉱山 & $m, c$. 短柱状 \\
\hline " 尾去沢鉱山 & \multirow{2}{*}{$\frac{m, c \text { よりなる }}{c, m . \text { 稀に小さく } a .}$} & 山形県午房野 & $m, c . \quad \prime \prime$ \\
\hline " 旭鉣山 & & \multirow{2}{*}{ 岐皁県神風鈗山 } & \multirow{2}{*}{$m, c . \quad \prime \prime$} \\
\hline 石川県高見鉱山 & \multirow{2}{*}{$\frac{\prime \prime}{m, c, x, a \text {. 針〜長柱状 }}$} & & \\
\hline " 尾小屋航山 & & \multirow{2}{*}{ 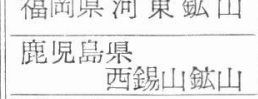 } & $m, c$. 短柱～長柱 \\
\hline \multirow{2}{*}{$\begin{array}{r}\text { 埼玉県秩父鈗山 } \\
\text { 大黒鈜床 }\end{array}$} & \multirow[b]{2}{*}{$m, c, x . \quad " \prime \prime$} & & $m, c$. 短柱 \\
\hline & & $\begin{array}{c}\text { *埼玉県 } \\
\text { 秩父鈗山赤岩 }\end{array}$ & $m, c$ \\
\hline 宮城県地円鈗山 & $\begin{array}{l}m, c, x . \text { または } m, x \\
\text { の錐形 }\end{array}$ & 忮皁県洞戸鉱山 & $\begin{array}{l}m, c, x . \text { 及び } x \text { の錐 } \\
\text { 体 (?) }\end{array}$ \\
\hline 石川県鍋戸鈗山 & $c, m, a, x$ & *大分罧観音滝鉱山 & $c, m$, 小さく $a$. \\
\hline 静岡県三倉鉣山 & $\begin{array}{l}m, c, x . \text { または } x の \\
\text { 大なる錐形 }\end{array}$ & *宮崎景土呂久鉱山 & $\begin{array}{l}\text { 六方錐及び六方柱, } \\
\text { 時に底面 (?) を有す }\end{array}$ \\
\hline 福岡県河 東鉱山 & $m, c, x$ & "長崎県成相啋旧坑 & $\begin{array}{l}x, m, c . \text { また } x \text { の錐 } \\
\text { 体 }(?)\end{array}$ \\
\hline
\end{tabular}

[註] $a(11 \overline{2} 0), m(10 \overline{1} 0), c(0001), x(10 \overline{1} 1)$

*ミメット鈗，他沈いずれすリヨクエン鉱。 


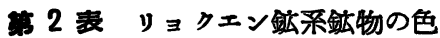

\begin{tabular}{|c|c|c|c|}
\hline 鉱物名 & $\begin{array}{c}\text { Pyromorphite } \\
\mathrm{Pb}_{5}\left(\mathrm{PO}_{4}, \mathrm{AsO}_{4}\right){ }_{3} \mathrm{Cl} \\
\end{array}$ & $\begin{array}{c}\text { Mimetite } \\
\mathrm{Pb}_{5}\left(\mathrm{AsO}_{4}, \mathrm{PO}_{4}\right)_{3} \mathrm{Cl} \\
\end{array}$ & $\begin{array}{c}\text { Vanadinite } \\
\mathrm{Pb}_{5}\left(\mathrm{VO}_{4}\right)_{3} \mathrm{Cl}\end{array}$ \\
\hline $\begin{array}{l}\text { 主 } \\
\text { な } \\
\text { 色 }\end{array}$ & $\begin{array}{l}\text { 緑, 黄, 褐 } \\
\text { ワックス黄 } \\
\text { オレンヂ 黄 } \\
\text { 褐赤, 紫褐 } \\
\text { 灰, 稀に無色 }\end{array}$ & $\begin{array}{l}\text { 焱黄〜黄褐 } \\
\text { オレンヂ 黄 } \\
\text { 白〜無 色 }\end{array}$ & $\begin{array}{l}\text { オレンヂ赤 } \\
\text { ルビー赤 } \\
\text { 带赤褐, 襡 } \\
\text { 带褐黄, 黄 } \\
\text { 淡葍 黄 }\end{array}$ \\
\hline
\end{tabular}

との間には，第2 表のよらにあるり規則的な関係は見出されない。たら゙しミ メット鉱は黄, バナヂン鉱は赤, または黄, リョクェン鉱では緑または黄色 を示すものがとくに多い3)。ゆえにリョクエン鉱とミメット鉱とが混晶をな し，累帯的に外部病ぞミメット钩成分に富む場合，たとえば大分県観音滝旧 坑産のものでは，中心部よりる外部症ぞやや黄色味を增するのがある゙。し かし一方てのような変化をみない試料も㐫るので，緑 黄に至る変化がたよ゙ 単に七素の增減にのみ影響されるか石かは問題が西る。とくにリョクエン鉱 につレては Leonhard4) は緑色種リョクェン钩に $0.66 \% \mathrm{As}_{2} \mathrm{O}_{5}$ のヒ素 を検出したてもからわらす，黄色種では全く七素を含まず, 彼注逆に緑色の

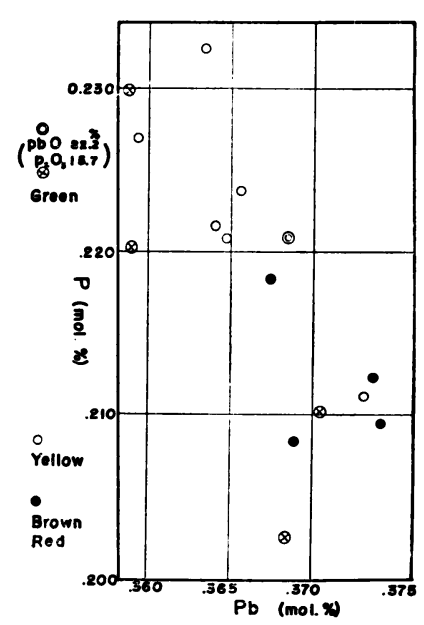

第4図リョクエン鉱の色と主 成分 $(\mathrm{Pb}$ 及び $\mathrm{P})$ との関係
呈色の原因にヒ素の影響を暗示している。

Heddle $^{5}$ 及び Bowles ${ }^{6}$ 等は黄色種は 緑色種より僅か儿鉄の含量の高いととか ら, 黄色種は微量含まれるリン酸鉄**の影 響ではないかと考えた。まを緑色種にはし ばしば微量の銅及びクロムを含むものがあ り，てれらの影響で緑色を示すのではない かといら考えも西つたが，てれは Bowles に上つて否定された。さらにカルシウムに 富むものでは，一般に褐〜黄灰色を示す ものが多いがてれも確かを傾向とはいえを n。

第4 図ではリョクエン鉱（含ヒ素リョク エン鉱, ミメット鉱を除く) 中の $\mathrm{P}: \mathrm{Pb}$

* 別報に詳述する。

** リン酸鉄は淡黄〜黄色を示す。 
と色との関係を示した。概して緑〜黄色種は赤褐〜紫袙色種に比へてや〉

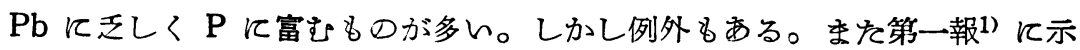
した X 線粉末写真の結果より，色と網面間隔との関連性を検討したが，な

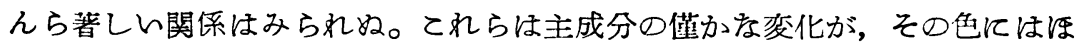
とんぞ影響を及ばさねととを意味するものであろう。

そてで第1四に示した微量成分とその試料の色との関係を考察すれば，ま ホ緑〜黄色種は赤褐〜紫褐色種に比へて微量成分の種類に富み, とくに Ca, As 及び V の上5をその構造の一部を交代して含まれると思われる微量成

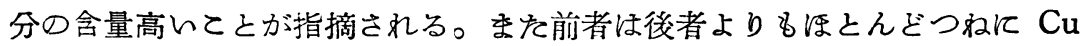
の含量沉乏しく（しかし河東鉱山，西錫山黄色種では $0.0 n \%$ ), Fe 亿富む。 すをわら赤褐〜紫褐色種中には平均 $0.0 n \%$ ○ $0 \mathrm{Cu}$ を含むが，緑～黄色種 は $0.0 n \%$ しくはそれ以下で, 明らかに銅に少んものが多ん。とくに尾小 屋, 地円, 尾去沢及び三倉鉱山産ひものはんすれる Cuの外には, ごく微量 (0.00n 0.000n\% また江以下) の $\mathrm{Ag}, \mathrm{V}, \mathrm{Ca}$ 等を含むのみでますます

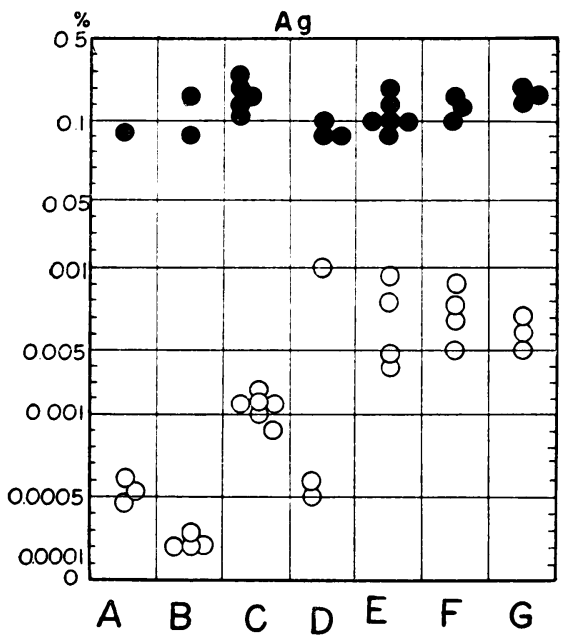

第 5 図-(a) ホウェン鉣○及びリョク エン鉱系鉣物○中の $\mathrm{Ag}$ 含有量

$\mathrm{A}$ 尾小屋, B 尾去沢, C 河東, D 西 錫山, E観音滰, $\mathrm{F}$ 秩父, $\mathrm{G}$ 成相啋
$\mathrm{Cu}$ と紫褐色種との関係は密にな る。ての事実は, 紫褐色種のつね に共通した特徽とるいえる。

しかし黃または緑色種の間では 上述のよらな共通した規則西る変 化を認めず, 僅かに黄色種が緑色 種よりも Fe 飞富むものが多い。

こっで微量成分と色との関係を 総括すれば (i) 赤〜紫褐色種は 一般にCuに富み,かつつね含ま れる。(ii) 黄及び緑色種の間では あまり著しい相違はみられぬが， 前者がやや Fe 亿富さ場合多く， Heddle 等が述べたりン酸鉄の影 響が考えられる。(iii)一般に黄及 び緑色種は紫褐色種に比べて, Ca,

* 分光分析の際，銅の炭素支持棒を使用した〉め，銅の分析結果は，湿式分析結果よ り稍々高めに検出される傾向がある。 


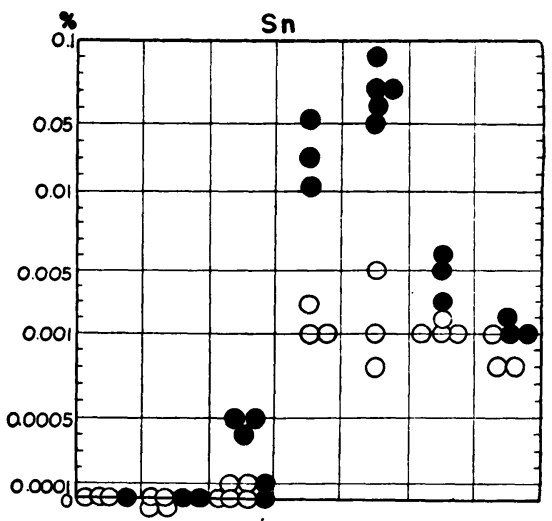

$A \begin{array}{llllll}A & D & E & F & G\end{array}$

第 5 四-(b) ホウェン鉱仅びリョ クエン鈗采鉱物 $\mathrm{O}$ 中の $\mathrm{Sn}$ 含有量 $\mathrm{A}$ 尾小屋, $\mathrm{B}$ 尾去沢, C河東, $\mathrm{D}$ 西 錫山, E 観音滰, F 秩父, G 成相啋

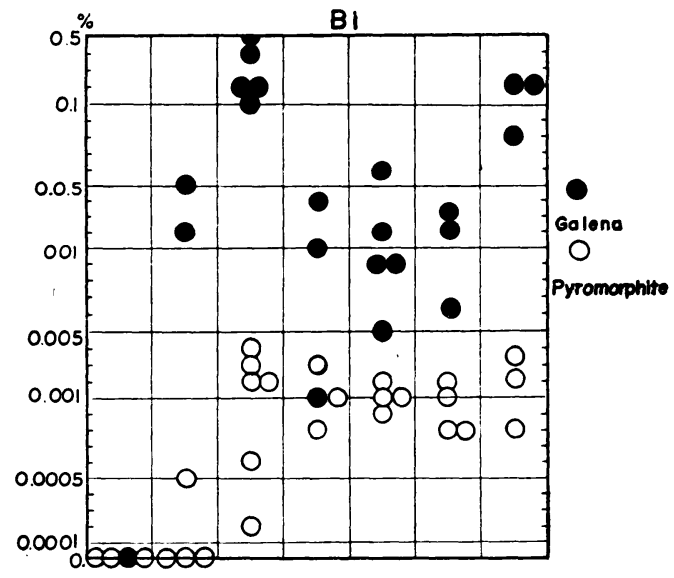

A $\quad B \quad C \quad D \quad E \quad F \quad G$

第 5 図-(c) ホウェン鉱级びעョク エン鉱系鉱物 $\mathrm{O}$ 中の $\mathrm{Bi}$ 含有量

$\mathrm{A}$ 尾小屋, $\mathrm{B}$ 尾去沢, $\mathrm{C}$ 河東, $\mathrm{D}$ 西錫 山, $\mathrm{E}$ 観音滰, $\mathrm{F}$ 秩父, $\mathrm{G}$ 成相啋
$\mathrm{V}$ ，As 等その他の微量 成 分の含量に富むが，後者は $\mathrm{Cu}$ 以外の成分に乏しん。 從つて黄及び緑色となる原 因の一つに Ca, V 及び As のようと構造の一部を交代 して含まれると思われる微 量成分の影響が考えられ る。(iv) 主成分 $(\mathrm{Pb}, \mathrm{P})$ の微 量な変化は色と関係なん。 しかしミメット鉱はんすれ も黄色なので，七素が相当 含まれた場合には黄色とな る傾向が西る。

以上の結果から，前述し た赤〜紫褐色種での $\boldsymbol{x}$ 面発 達著しい現象は，リョクエ ソ鉱中の $\mathrm{Cu} の$ 含量と関係 あるようと思われる。

\section{4. 初生鉱床の成因と リョクエン鉱系鉱 物中の含有成分と の関係}

第1因に示した試料の産 地を成因別飞分つと，第三 紀火山岩類几成因関係㐫る 低温熱水鉱床（尾小屋, 地 円, 三倉, 尾去沢, 舶山盛, 大玫), 第三紀カコウ岩類 飞件う中温～高温熱水鉱㕅 （観音滝，西錫山，成相啋） 及び接触鉱床 (秩父), 中 


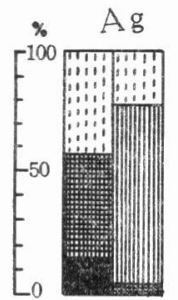

L. $H$.

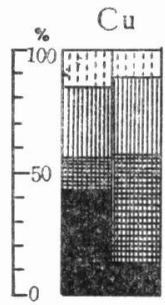

L. $\mathrm{H}$.

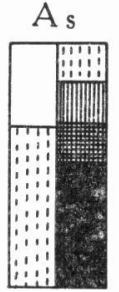

L. $H$.

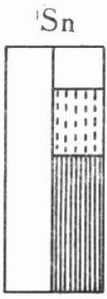

L. $\mathrm{H}$.

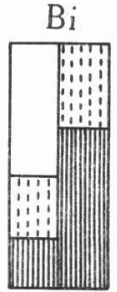

L. $H$.

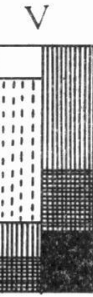

L. $\mathrm{H}$

第 6 図 鉱床の型とリョクエン 鉱系鉣物中の微量成分との関係

L：浅熱水鉱床（火山岩類に

伴弓） $\mathrm{H}$ : 中温～高温鉱床

(カエウ岩類に伴ろ)。

黑色部： $0 . n \%$, 格子部： 0 . $0 n \%$, 実線部: $0.00 n \%$, 点 線部： $0.000 n \%$, 白色部： ? または 0 。

生代カコウ岩類に件弓中温熱水鉱床 (河東) 産のるのに分たれる。乙れら 孝浅熱水鉱床（火山岩類江件5）上中 ～高温熱水鉱床（カコッ岩類に件ら） とに分つて検討すれば，第6図のよ5 に, 前者では $\mathrm{Cu}, \mathrm{Ag}$ にみ, 後者で は $\mathrm{As}, \mathrm{Bi}, \mathrm{V}$ 及び $\mathrm{Sn}$ にとむ。とく に Bi, Sn 及び As は後者で極めて増 加する。第 5 図 a-c にリョクエン鉱 系鉱物中の $\mathrm{Ag}, \mathrm{Bi}$ 及び $\mathrm{Sn}$ 分析值 走示しれが，尾小屋及び尾去沢鉱山産 のものは $\mathrm{Sn}$ 及ぴ $\mathrm{Bi}$ ともに全く含ま ぬか,まをは極めて微量 $(0.0005 \% \mathrm{Bi}$ 以下) に過ぎ。しかし西錫山，観音 滝, 成相啋及び秩父産のものは, Bi 0 . $004 \sim 0.0008 \%$, Sn 0. 005 0.0008\% で, 前者より明らかに多ん。

一方酸性深成岩類に件らものでも， 第三紀カコウ岩類と中生代カコウ岩類 に分つて，その各ふについて検討すれ ば, その最も著しい特徴として, 後者 はつねに Sn に文しんととが挙げられる。たとえば第 5 図bのよ5に，中 生代カコウ岩類に件ら河東鉱山産リョクエン鉱は 0.0001\% Snまたはとれ以 下で，第三紀カコウ岩類に件ら鉱床産のもの（その多くが 0.001\% 内外）に 比べて非常に少い。

以上のよ5を傾向はんホれ夕ホウェン鉱中の微量成分の分布と全く同様 で，この関係は第 5 図 $\mathrm{a} \sim c$ で良く分る。従つてホウエン鉱中の微量成 分が，之秃を産する鈗床の特徴を良く示す8，と同様に，リョクエン鉱系鉱物

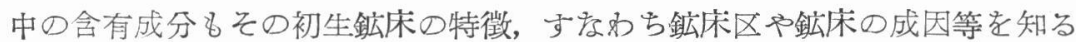
上に重要看掛りとなる。むしろ後述のように二次的にある種の元素のみが とくに再濃集することも西るので, かえつて初生鉱物中よりも鉱床の特徴を

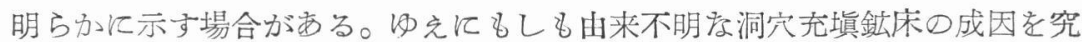


ー 28 - 本邦産リョクエン鉱ミメット鉱柔鉱物について（第二報）
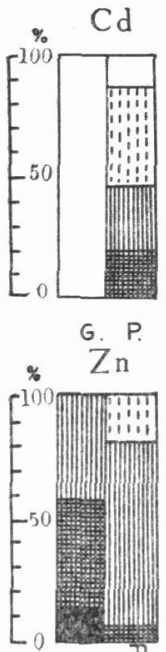

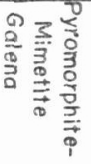

$\mathrm{Ag}$

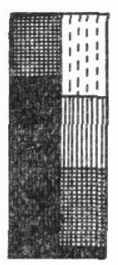

G. P.
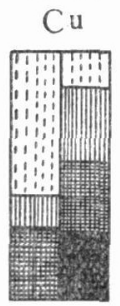

G. P.

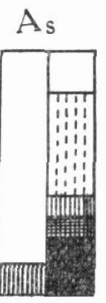

G. P.

$\mathrm{Sb}$

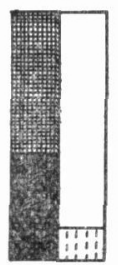

G. P.
$\mathrm{Ba}$

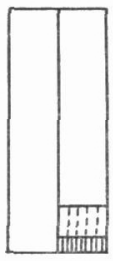

G. P

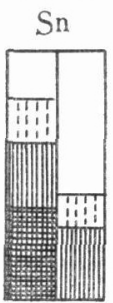

G. P.

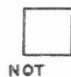

NOT
$\mathrm{Bi}$

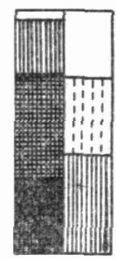

G. P.

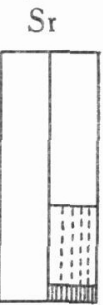

G. $P$.
$\mathrm{Ca}$

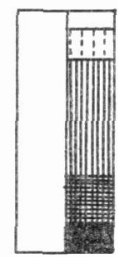

G. P

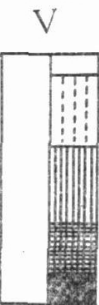

G. P.

第 7 図 ホウエン鉱中及びリョクエン鉱系鉱物中の微量成分の比較

明する場合や，酸化著し々露頭部の調查老行万際に注，之くにてれら二次鉱 物中の微量成分を充分検討する必要が㐫る。

\section{5. ホウエン鉱中の微量成分との違い}

第1罒にリョクエン鉱系鉱物の源之密接存成因関係に西共生鉱物の含有 成分を示しを。て礼らのらちリョクエン鉱中の含有成分 $\mathrm{Cl}$ 及び $\mathrm{P}$ 定除く と，他活ホウェン鉱の含有成分の傾向に近似する。

ホウエン鉱に比へて増加もしくは新しく附加されを成分には, $\mathrm{As}, \mathrm{V}, \mathrm{Cu}$, $\mathrm{Cd}, \mathrm{Ba}, \mathrm{Ca}, \mathrm{Sr}, \mathrm{P}$ 及び $\mathrm{Cl}$ 等が要り, 逆泟少する成分にほ, $\mathrm{Ag}, \mathrm{Bi}, \mathrm{Zn}$, $\mathrm{Sb}$ 及び $\mathrm{Sn}$ 等が西る（第 7 図）。增加定示す場合にはホウェン鉱と密飞共 生する鉱物の種類に強く支配されるとともある゙（七ンアエン鉱，オウドウ 鉱及びリュウヒテツ鉱と共生するをめ,リョクェン鉱系鉱物中に $\mathrm{Zn}, \mathrm{Cd}, \mathrm{Cu}$ 及び As が多い等) むしろ循環水中の微量溶解元素のらちリョクエン鉱系 鉱物の主成分元素とイオン半径やその他のイオンの諸性質を近似するか, ま 


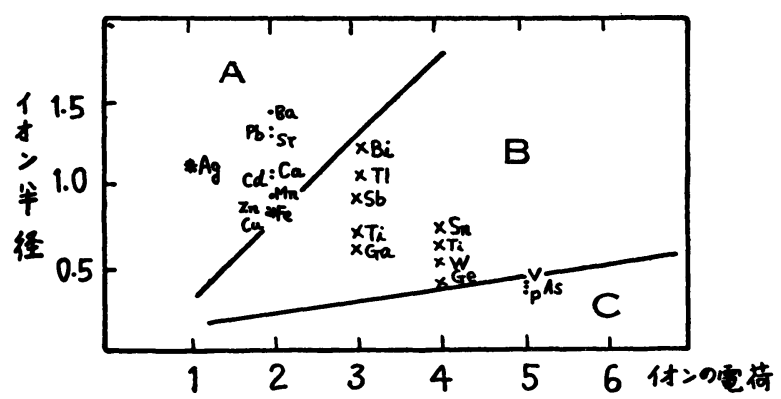

第 8 図 リョクエン鈗采鈜物及び共生初生鉣物中の含有成 分のイオンポテンシャルによる区分表

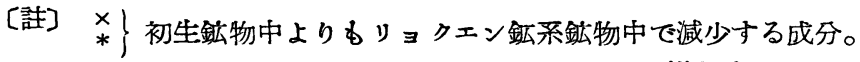
$\mathrm{A}$
$\mathrm{B}$
$\mathrm{C}$
"I
"
增加する
A イオンポテンシャル 3 以下 （可榕性陽イオン）
B " $\quad 3 \sim 12$ (水解体 元素)
C 12 以上（可溶性陰錯イオン）

をは同型の鉱物を作る元素に限られる。をとえば初生鉱物中に含ヒ素鉱物を みなん場合でも、リョクェン鉱中にはAs 学認めるものが多ん。（大玟，河 東, 三倉山等)。また V ゃ $\mathrm{Sr}$ 及び $\mathrm{Ba}$ 等につんても同様をてとがんえる。 たぐしての場合でも初生鉱床の特徴はあくまでもたもをれる。すなわち初生 鉱床の含有成分（鉱石及び脈石鉱物ともに）の5ち，西成分が敏感に二次 鉱物中に再配分，かつ濃集されるので，二次鉱物中の含有成分のもつ意義 は，地球化学的を地表水による移動集積という立場から，また一方鉱休の特 徵を推知する鉱床学的な立場のんすれれかる重要でする。

リョクエン鉱系鉱物の含有成分を支配する要素の一つにイオンのもつ性質 が挙げられるが，イオンポテンシャル9）に例をとれば第 8 図のような関係 がある。罒で左上の直線はイオンポテンシャル 3.0 を示し，ての線の左側 は低んイォンポテンシャルの元素で, これらは風化作用の際には可溶性陽イ オンとして地表水中に溶ける。ホウェン鉱にくらへてリョクエン鉱中で增加 する元素のちち $\mathrm{Cu}, \mathrm{Ba}, \mathrm{Ca}, \mathrm{Sr}$ 等はんすれれての域に属する。因の右下の 直線はイオンポテンシャル 12 を示し，ての線の右側のイオンポテンシャル の高ん元素も，前者と同様可溶性院錯イォンとして地表水中に溶ける。 $\mathrm{V}$, $\mathrm{As}, \mathrm{Cl}$ 及び $\mathrm{P}$ 等, んすれるホウェン鉱に比べて増加する成分がてれに属す る。前二者の中間に位置するイオンポテンシャル 3〜12 のイオンは, 水溶 
液からの水酸基と結合し加水分解を起して沈澱し，水酸化物を残留する。リ ョクエン鉱中で減少する $\mathrm{Bi}, \mathrm{Tl}, \mathrm{Sb}, \mathrm{Ti}, \mathrm{Ga}, \mathrm{Sn}, \mathrm{W}, \mathrm{Ge}$ 等はんホれるて の域に西る。これはホウェン鉱中の $\mathrm{Pb}$ が地表水中に可溶性陽イオンとして 溶解し, 溶液中の $\mathrm{P}, \mathrm{Cl}$ 等の可溶性陰錯イオンとの反応によつて生じた〉 めで、ボーキサイト鉱床9)のよらな残留鉱床にみられる元素の集りとは, 全 く相反した行動を示す。

第 5 田 (a)には同一鉱床より得られたホウェン鉱及びリョクェン鉱中の各 々の Agの含量を示した。Agのイオンポテンシャルは 0.88 で, 3 より小さ く, 当然可溶性陽イオンに属するにもかわらず,リョクェン鉱中では極めて 減少する。これは $\mathrm{Ag}$ と $\mathrm{Pb}$ とのイオン半径 $\left(\mathrm{Pb}^{2+1.32 \AA ̊, ~} \mathrm{Ag}^{+} 1.13 \AA\right) \oslash$ 違い（ホウェン鉱中では $\mathrm{Ag}$ は $\mathrm{Pb}$ を交代して含まれるのではなく，四つ の最も近んSイオンからなる四面体の中に Agイォンは捕獲されてある10)。 ゆえに構造が変化すると Ag イオンは入るてとができなくなる）や両者の redox potential が異るとと等に起因するるのと思われる。

\section{6. 結 び}

（i ）リョクエン鉱のなかで赤褐〜紫褐色のものは $x$ 面の発達良好なもの が多い。

（ii）リョクエン鉱の色は主として青〜緑, 黄 及び紫褐色の三つに分たれ るが, それらの違いは主化学成分 $(\mathrm{Pb}, \mathrm{P})$ の変化上りも微量成分, とくに $\mathrm{Cu}$, As, V, Ca 等関係がある。

(iii）リョクエン鉱系鉱物の含有成分のうち, ホウェン鉱より増加する成 分は, いホれるイオンポテンシャル 3 以下るしくは 12 以上の元素に限られ る。減少する成分は 3 12 の間の元素である。

(iv) リョクエン鉱系鉱物の微量成分は，それを産する鉱床の初生鉱物（と (飞ホウェン鉱）の微量成分の傾向之同様であり, 鉱床の成因や, 鉱床区等 鉱休の特徵知る上て重要である。むしろ時には再濃集作用の結果, かえつ て初生鉱物よりるその特徽を明らかにする場合が㐫る。

〔謝辞】本研究に際して色々と御指導を賜つた木下亀城教授に厚く御礼申 上げる。また貴重な試料をお分ちいたら゙いた岡本要八郎請師及び宮久三干年 氏に深く謝意を表する。 


\section{文䰚}

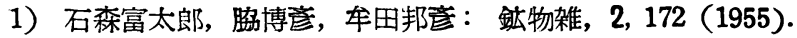

2）伊藤貞市, 桜井欽一：日本铈物誌 (上巻) (1947).

3) C. Palache and C. Frondel: Dana's System of Mineralogy, Vol. 2, 7th ed. 889 (1951).

4) L. Leonhard: N. Jahrbuch für Min. und Geol., 449 (1869).

5) H. Heddle: Min. Mag., 5, 21 (1882).

6) O. Bowles: Am. Jour. Sci., 178, 40 (1909).

7）军田邦：日本鉱業大会, 福岡総会 (1952).

" " "：日本地質学会京都総会講演 (1956).

8) K. Rankama and Th. G. Sahama: Geochemistry (Univ. Chicago), 236 (1949).

9) M. Gordon and K. J. Murata: Econ. Geol., 47, 169 (1952).

10) V. M. Goldschmidt : Geochemistry (Univ. Oxford), 398 (1954).

(1956 年 6 月 8 日受理)

\section{岩手県上根市座アラレ石}

岩手県宫古市千徳町上根市ではカコゥセンリョク岩の接触を受けたクカイ岩を採風 しており,ここよりコトウ石, ルドゥィヒ石, ザイベリ石, ワーウィク石, コンドロ 石, トゥキ石, クドカンラン石, キンウンモ, ケイカイ石, スピネルその他種種の銥 物を産し, 学術上興味梁い。この地のコトウ石大理石のわれ目に無色透明の細柱状結 晶をなしてナラレ石が産する。結晶の長さは $1 \mathrm{~cm}$ ぐらいで菊の花に似た放射状の集 合をなし球状を呈さない。塩酸でたやすく発泡することによつて外勧類似するザイべ リ石と識別することが出来, さらに延長方向が負であることによつてアラレ石と決定 しだアラレ石がセッカイ岩またはクカイ岩のわれ目に産する例はきわめて稀であり， 本邦においてはまだ知られていない。(加藤 昭) 